\title{
DE BETEEKENIS VAN HET WOORD DALANG.
}

\author{
DOOR
}

R. A. KERN.

In het Soendasche woordenboek van Rigg wordt de dalang, de vertooner van het schimmentooneel padalang genoemd. Rigg registreerde de taal van Djasinga, waar hij landheer was, in het Westen van Buitenzorg op de Bantěn'sche grens; men spreekt er een in vele opzichten ouderwetsch Soendaasch.

Het prefix pa- vormt o.m. namen van personen die zich onledig houden met wat het gw. uitdrukt, bv. padagang - handelaar, Jav. padagang - factoor ${ }^{1}$ ). Naast pa- komt $\mathrm{pa}^{\mathrm{ng}}-$ - voor, soms beiden bij een zelfde gw., bv. pakěbon en pangěbon, van kĕbon-tuin; het eerste is letterlijk tuin-man, een man die er een tuin op nahoudt, het tweede iemand die een tuin als bedrijf bewerkt, het spraakgebruik makt geen verschil, beide woorden beteekenen ,tuinder”. Een voorbeeld van het sedert lang niet meer levend prefix par- levert paradji - vroedvrouw, lett. iemand die magische spreuken of formulieren (adji) kan prevelen, in sommige deelen van ons land zou men zeggen: ,die 't kan besprèken”. Inderdaad is dit een voornaam deel van het werk der vroedvrouw.

Rigg geeft nog een paar voorbeelden dat het prefix $p a$ - is bewaard, terwijl het elders in het Soend. en in het Jav. niet meer aanwezig is : pabegal, Jav. begal - straatroover, palawan, Jav. lawan - tegenpartij, „partner”. Uit den vorm padalang wordt dus duidelijk dat dalang een eigen beteekenis heeft, doch welke? Eenige Filippijnsche talen bezitten een woord lalang dat etymologisch = Jav. dalang is. Vgl. Tag. lalim, Bik. Bis. lalom, Pomp. lalam, Mlg. lalina, B.M. dalom, het diepe, Tont. rarĕm - onder, beneden, diep (ook: binnenste, zie voorbeelden in het wb.), Tb. lalěm, rarěm, Boeg. lalěng, Mak. lalang — het binnenste, O.-Jav. d̦alěman - ingewand, O. en N. Jav. dalĕm-

1) Voor denzelfden vorm in andere Indonesische talen, zie men deel 92 dezer Bijdragen, bl. 16 v.v. 
het binnenste. - Tag. paglalang, paglalalang is schepping, instelling, uitvinding, vaardigheid, in ongunstigen zin: list, kunstgreep, machinatie, intrige; ang linalang — de Schepping; linalang — schepsel, creatuur; Bis lalang - project, geschiktheid tot iets, krijgslist, list, ook: paglalang; gilaláng kiní sa Dios - dit is het werk, de beschikking van God; Bik. malalang - een vindingrijk man; Pamp. lalang deugd, vermogen, begrip, wijsheid waarmee men ontwerpt, uitvindt of moeilijke zaken licht maakt, bekwaamheid, vindingrijkheid, nimmer in ongunstigen zin. Misschien is Day. lalangan - schijn, ook hiermee in verband te brengen.

In lalang ligt dus het begrip „creëeren met verstand, begrip e.d.” en de padalang is de man die met vernuft ten tooneele brengt, de man eener creatie, een benaming die tevens een eerbetoon inhoudt.

Leiden, Maart 1938. 